International Journal of Social Science And Human Research

ISSN(print): 2644-0679, ISSN(online): 2644-0695

Volume 03 Issue 09 September 2020

DOI: $10.47191 /$ ijsshr/v3-i9-04

Page No.-147-154

\title{
Mixed Methods Research: An Overview
}

\author{
Nasser Alasmari \\ University of Jeddah
}

\begin{abstract}
One critical aspect of good research is the methodology that is used to logically correlate the aims and goals of the study and the answers to the research questions. Rajasekar et al. (2006) defined research methodology as "the procedures by which researches go about their work of describing and predicting phenomena" (p. 2). This section aimed to shed lights on mixed methods, quantitative and qualitative approaches and its applications.
\end{abstract}

\section{MIXED METHODS RESEARCH: COMBINING QUANTITATIVE AND QUALITATIVE APPROACHES}

There are a number of similar definitions for the mixed methods research design. Greene, Caracelli and Graham (1989) define it as research that includes one or more methods to collect data comprised of numbers (quantitative) or words (qualitative). Similarly, Tashakkori and Teddlie (1998) define it as research that combines both quantitative and qualitative approaches in its methodology. Creswell (2003) states that, in the mixed methods approach, the researcher collects, analyses and integrates both quantitative and qualitative data in a single study or in multiple studies in a sustained program of inquiry. Johnson and Onwuegbuzie (2004) expand this definition to say that the researcher, in a single study, uses a combination of quantitative and qualitative methods, approaches, concepts or language. Creswell and Clark (2007) supply a thorough definition for mixed methods research, stating:

"Mixed methods research is a research design with philosophical assumptions as well as methods of inquiry. As a methodology, it involves philosophical assumptions that guide the direction of the collection and analysis of data and the mixture of qualitative and quantitative approaches in many phases in the research process. As a method, it focuses on collecting, analysing, and mixing both quantitative and qualitative data in a single study or series of studies. Its central premise is that the use of quantitative and qualitative approaches in combination provides a better understanding of research problems than either approach alone" (p. 5)

Creswell (2003) mentions two main factors that help researchers to design their studies: data collection implementation and priority. Data collection implementation refers to the order that the researcher follows to collect both quantitative and qualitative data. Consequently, three strategies are associated with mixed methods research (Molina and Cameron, 2010). The first strategy is the sequential (or two phase) design, in which the researcher starts collecting qualitative data for exploration purposes, followed by the collection of quantitative data for generalising the research results. Alternatively, the researcher starts examining the research's concepts by collecting quantitative data followed by qualitative data for a more detailed exploration of the individual findings or cases.

The second strategy associated with mixed methods research is concurrent (simultaneous or parallel) procedures. When using this strategy, the researcher collects both quantitative and qualitative data simultaneously, and then integrates the collected data in an interpretation of the overall results to offer a comprehensive analysis of the research problem (Creswell, 2003). If the collection of the qualitative data precedes that of the quantitative data, the researcher aims to first explore the research issue through the quantitative data and then qualitatively deepen the study sample for specification. On the other hand, if the collection of quantitative data precedes the collection of qualitative data, the researcher is intending to include a large sample of data to test the research's variables and then to deepen the investigation of individual or minor cases, subsequently using the qualitative method (Molina and Cameron, 2010).

The third strategy associated with mixed methods research is the transformative design, in which "the researcher uses a theoretical lens as an overarching perspective within a design that contains both quantitative and qualitative data" (Creswell, 2003, p. 16). Methodologically, using the lens of this design provides the framework for a chosen topic, a sequential or concurrent approach to data collection methods, and the expected outcomes.

1. Equivalent status/ simultaneous designs: QUAL + QUAN.

2. Equivalent status/ sequential designs: QUAL $\rightarrow$ QUAN; QUAN $\rightarrow$ QUAL.

3. Dominant/ simultaneous designs: QUAL + quan; QUAN + qual. 
4. Dominant/ sequential designs: qual $\rightarrow$ QUAN; QUAL $\rightarrow$ quan; quan $\rightarrow$ QUAL; QUAN $\rightarrow$ qual.

- The letters qual or QUAL stands for qualitative research.

- The letters quan or QUAN stands for quantitative research.

- Capital letters denote priority or increased weigh.

- Lowercase letters denote lower priority or weight.

- A plus sign (+) represents a concurrent collection of data

- An arrow sign $(\rightarrow)$ represents a sequential collection of data.

In reference to the priority factor, the quantitative or qualitative parts of a study can be treated as equal in priority or more emphasis can be placed on one of the parts. This emphasis results either from the lead researcher's direction or is related to the research's paradigm: the research questions, participants' preference or data collection difficulties. Accordingly, mixed methods research can be divided into two types of designs: equivalent category or nested designs. In equivalent category, the researcher equally uses both quantitative and qualitative approaches to achieve a full understanding of the phenomenon under study. On the other hand, in the nested or dominant-less dominant design, the researcher conducts the study in one dominant paradigm (quantitative or qualitative) with a small part of the overall study sample (qualitative or quantitative) in the dominant-less paradigm. Johnson and Onwuegbuzie (2004) clarify that these two dimensions can lead to four groups and nine types of mixed methods designs:

Table 3 - 1 Mixed methods design (Johnson \& Onwuegbuzie, 2004 \& Johnson \& Christensen, 2012)

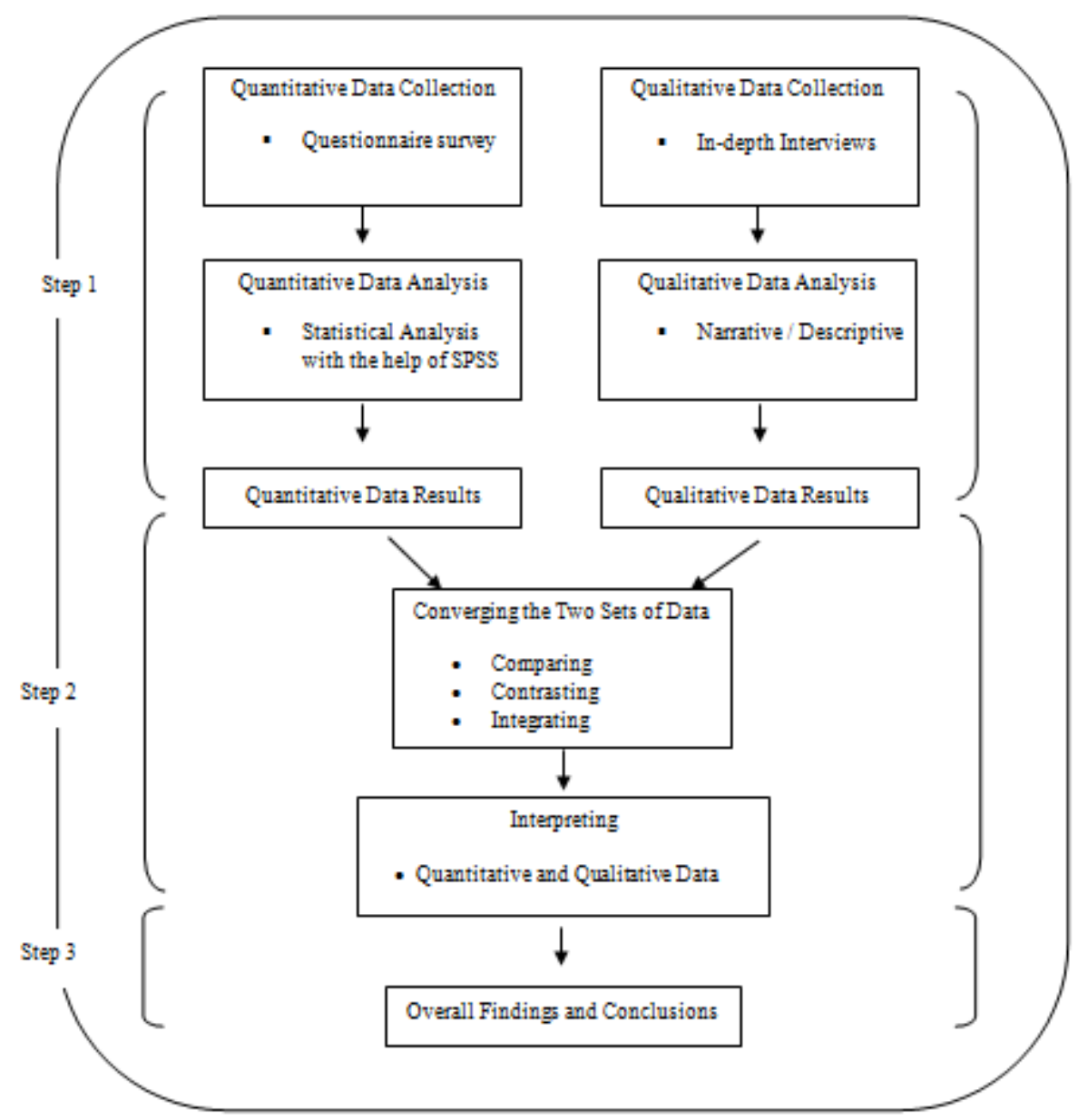

Figure 3-2: The methodological procedure (Jenkins, 2001)

Administration of qualitative research along with quantitative research leads to a deeper interpretation and thoughtful understanding of the complicated numeric findings of quantitative data (Duff, 2002). Therefore, the present research applies a dominant/sequential design (QUAN $\rightarrow$ qual), which is a process whereby the quantitative part of the study is the dominant source of data; the data will be collected sequentially, starting with quantitative data and ending with qualitative data. 


\section{Mixed Methods Research: An Overview}

\section{QUANTITATIVE VS QUALITATIVE}

Flexibility is the key difference between quantitative and qualitative methods. Generally, in quantitative research, the researcher asks the study participants to respond to a set of identical close-ended or fixed questions in a similar order in a survey or a questionnaire. The inflexibility of quantitative research allows for comparisons between the participants' responses and contexts. On the other hand, qualitative research is more flexible and allows for extra interaction with participants and in-depth open-ended questions (Mack et al., 2005). In a general view, Creswell (2005) states:

"Quantitative research is a type of educational research in which the researcher decides what to study, asks specific, narrow questions, collects numeric (numbered) data from participants, analyses these numbers using statistics, and conducts the inquiry in an unbiased, objective manner. Qualitative research is a type of educational research in which the researcher relies on the views of participants, asks broad, general questions, collects data consisting largely of words (or text) from participants, describes and analyses these words for themes, and conducts the inquiry in a subjective, biased manner". (p. 39)

Table (3-2) exemplifies some of the main differences between quantitative and qualitative research.

\begin{tabular}{|c|c|c|}
\hline & Quantitative & Qualitative \\
\hline $\begin{array}{l}\text { Scientific } \\
\text { method }\end{array}$ & $\begin{array}{l}\text { Deductive or "top-down" } \\
\text { The researcher tests } \\
\text { hypotheses and theory with data }\end{array}$ & $\begin{array}{l}\text { Inductive or "bottom-up" } \\
\text { The researcher generates new } \\
\text { hypotheses and grounded theory from } \\
\text { data collected during fieldwork }\end{array}$ \\
\hline $\begin{array}{l}\text { View of human } \\
\text { behaviour }\end{array}$ & Behaviour is regular and predictable & $\begin{array}{l}\text { Behaviour is fluid, dynamic, } \\
\text { situational, } \\
\text { social, contextual, and personal }\end{array}$ \\
\hline $\begin{array}{l}\text { Most common } \\
\text { research objectives }\end{array}$ & $\begin{array}{l}\text { Description, explanation, and } \\
\text { prediction }\end{array}$ & $\begin{array}{l}\text { Description, exploration, and } \\
\text { discovery }\end{array}$ \\
\hline Focus & $\begin{array}{l}\text { Narrow-angle lens, testing } \\
\text { specific hypotheses }\end{array}$ & $\begin{array}{l}\text { Wide-angle and "deep-angle" lens, } \\
\text { examining the breadth and depth of } \\
\text { phenomena to learn more about them }\end{array}$ \\
\hline $\begin{array}{l}\text { Nature of } \\
\text { observation }\end{array}$ & $\begin{array}{l}\text { Attempt to study behavior } \\
\text { under controlled conditions }\end{array}$ & $\begin{array}{l}\text { Study behavior in natural } \\
\text { environments } \\
\text { Study the context in which behavior } \\
\text { occurs }\end{array}$ \\
\hline $\begin{array}{l}\text { Nature of } \\
\text { reality }\end{array}$ & $\begin{array}{l}\text { Objective (different observers } \\
\text { agree on what is observed) }\end{array}$ & $\begin{array}{l}\text { Subjective, personal, and socially } \\
\text { constructed }\end{array}$ \\
\hline $\begin{array}{l}\text { Form of data } \\
\text { collected }\end{array}$ & $\begin{array}{l}\text { Collect quantitative data based } \\
\text { on precise measurement using } \\
\text { structured and validated data } \\
\text { collection instruments (e.g., } \\
\text { closed-ended items, rating } \\
\text { scales, behavioural responses) }\end{array}$ & $\begin{array}{l}\text { Collect qualitative data (e.g., in-depth } \\
\text { interviews, participant observation, } \\
\text { field notes, and open-ended questions) } \\
\text { The researcher is the primary data } \\
\text { collection instrument }\end{array}$ \\
\hline Nature of data & Variables & Words, images, categories \\
\hline Data analysis & $\begin{array}{l}\text { Identify statistical } \\
\text { relationships }\end{array}$ & $\begin{array}{l}\text { Search for patterns, themes, and } \\
\text { holistic features }\end{array}$ \\
\hline Results & Generalisable findings & $\begin{array}{l}\text { Particularistic findings } \\
\text { Representation of insider (i.e., emic") } \\
\text { viewpoint } \\
\text { Present multiple perspectives }\end{array}$ \\
\hline $\begin{array}{l}\text { Form of final } \\
\text { Report }\end{array}$ & $\begin{array}{l}\text { Statistical report (e.g., with } \\
\text { correlations, comparisons of } \\
\text { means, and reporting of statistical } \\
\text { significance of findings) }\end{array}$ & $\begin{array}{l}\text { Narrative report with contextual } \\
\text { description and direct quotations from } \\
\text { research participants }\end{array}$ \\
\hline
\end{tabular}

Table 3-2: Differences between quan and qual. research (Johnson \& Christensen, 2012, pp 34-35) 


\section{Mixed Methods Research: An Overview}

\section{Rationale for the Quantitative Approach}

One may immediately think of numbers and statistics when first considering quantitative methods (Muijs, 2011). Since around 1250 A.D., quantitative research has been the dominant research method used to produce meaning through objectivity and new knowledge (Williams, 2007). Identification of qualitative research varies with the purpose of the research matter. Leedy and Ormrod (2001) illustrate that, when quantitative research is used to clarify the relationship between the research and the variable questions, then "quantitative researchers seek explanations and predictions that will generate to other persons and places. The intent is to establish, confirm or validate relationships and to develop generalizations that contribute to theory" (p. 102). On the other hand, Creswell (2003) states that quantitative research "employs strategies of inquiry such as experimental and surveys and collects data on predetermined instruments that yield statistical data" (p. 18). Similarly, Muijs (2011) describes qualitative research as "explaining phenomena by collecting numerical data that are analysed using mathematically based methods (in particular statistics)" (p. 1).

The primary purpose of using quantitative research is to produce data in the form of numbers that can be aggregated and analysed to describe, predict and represent the truth (Sale et al., 2002). Muijs (2011) lists four types of research questions for which the quantitative approach is suitable. The first type is when the question demands a quantitative answer, such as "How many students choose to study education?" In such a case, the quantitative method is the only one that can fulfil the demand. The second type of quantitative approach is for answering questions related to numerical changes, such as evaluating an increase or decrease in the number of students. The third category is using quantitative research to explain a phenomenon or state of something, such as the factors related to changes in student achievement over time. Testing of a hypothesis is the final activity for which quantitative research is used.

In a broader format, Ary et al. (2010) propose that quantitative research may be classified as either experimental or nonexperimental. Leedy and Ormrod (2001) state that there are three main classifications of quantitative research: descriptive, experimental and causal comparative. Both of these views, in addition to that of Creswell (2003), lead to the same classification. The descriptive research method is a basic approach conducted to determine and/or describe the variables in the current state of a situation to gain the most information possible about a particular field of study (Williams, 2007). The essential goal of conducting descriptive research is to describe the variables of a particular phenomenon or, when there is more than one phenomenon, to explain the relationship between them (Gravetter \& Forzano, 2003).

The second type of quantitative research method is the experimental technique, in which the researcher tests a phenomenon under certain controlled conditions to determine a known truth or to examine the validity of a hypothesis and then measure the findings and outcomes (Muijs, 2011). Muijs further adds that the research environment must be controlled in experimental research and the focus of the study extended as much as possible to include the variables under investigation. Leedy and Ormrod (2001) state that there are three types of exploratory approaches: pre-experimental, true experimental and quasi-experimental. The preexperimental design is the simplest design as it does not involve a tolerable control group. On the other hand, true experimental design provides a higher degree of control and produces a higher degree of validity, whereas, the quasi-experimental design employs a means to compare groups with a random selection of study participants and limited control, which results in a lack of validity (Williams, 2007).

The third type of quantitative research method is causal-comparative research, which is also sometimes called ex post facto or after the fact. The purpose of conducting causal-comparative research is to categorize the relationship between the cause and the effect in a case where experimentation is not possible (Lodico et al., 2010). The distinction between causal-comparative research and experimental research is that the former does not involve the manipulation of variables, while the latter does (Fred, 2011). On the other hand, both methods share the same characteristics of involving more than one group and seeking to determine the relationship between cause and effect.

Quantitative research can be conducted in various forms, such as in descriptive, correlational, developmental, observational and survey research (Williams, 2007). A correlational research method is one in which a researcher can examine the characteristic differences of the participants in a study group (Leedy \& Ormrod, 2001). In the correlational technique, validity and reliability are important statistical calculation characteristics that affect coefficients of correlation. During the developmental design, the researcher uses a cross-sectional study to make comparisons between groups within the same parameters, and a longitudinal design to give a better understanding of a particular phenomenon over a specific period of time (Leedy \& Ormrod, 2001). In observational research methods, researchers objectively focus on the aspects of human behaviour. Survey research, which is one of the most common methods for gathering data in the social sciences, focuses on a particular phenomenon by sampling data from respondents that represent a targeted research population (Williams, 2007).

Muijs (2011) illustrated four types of issues that quantitative research fails to demonstrate. The first is that quantitative research cannot explore issues in depth because of its broad strategy of collecting data from a large number of units. The second issue is that quantitative research is suitable for testing theories and hypotheses, but it is inappropriate for developing them; qualitative research is much more useful for exploring developed theories and hypotheses. The third issue for which quantitative research is inappropriate is the treatment of a particular issue when it is complex or requires in-depth exploration. Finally, quantitative 


\section{Mixed Methods Research: An Overview}

research is a causality method best used for looking at cause and effect, while qualitative methods are used for exploring the meaning of an issue or phenomenon. Muijs (2011) recommends that the use of a mixed methods design, combining both quantitative and qualitative research methods, as used in the present research, will provide both breadth and depth of data analysis. Bryman (2004) demonstrates four aspects of the criticism of quantitative research. The first is that the quantitative model does not differentiate between the social and the natural world when an individual's interpretation of the world around him differs from the objects of natural science. The second aspect is the weak connection between real life and the developed measures in qualitative research. The third is that the researcher's reliance on instruments and procedures widens the gap between research and everyday life. One can ask how the participants' responses reflect their real sense of the topic, on one hand, and their awareness of its manifestation on the other. Finally, quantitative research ignores what events mean to individuals and how the findings of the research are connected to the everyday context.

\section{Rational for the Qualitative Approach}

The qualitative method is also used in scientific research. Shank (2002) defines qualitative research as "a form of systematic empirical inquiry into meaning" (p. 5). When he mentions "systematic", he means "planned, ordered and public". "Empirical" means that personal experience is the foundation of this type of inquiry. "Inquiry into meaning" indicates that the research tries to draw on the sense of other experiences and to interpret it (Ospina, 2004). Denzin and Lincoln (2005) provided an extra explanatory descriptive definition of qualitative research:

Qualitative research is an interdisciplinary, trans-disciplinary, and sometimes counter disciplinary field.

It crosscuts the humanities, the social sciences, and the physical sciences. Qualitative research is many things at the same time. It is multi-paradigmatic in focus. Its practitioners are sensitive to the value of the multi-method approach. They are committed to naturalistic perspective and to the interpretive understanding of human experience. At the same time, the field is inherently political and shaped by multiple ethical and political positions (Denzin \& Lincoln 2005, p. 7).

It appears that there is a stronger preference for adopting quantitative methods in research on students in higher education than for using qualitative methods (Grebennikove \& Skaines, 2007; Kashims \& Loh, 2006). However, the use of quantitative methods in higher education research does not diminish the use of qualitative methods. The strength of qualitative research comes from its naturalism and capability to describe complicated personal experiences in research issues or topics, which cannot be tested in quantitative research (Willis, 2008). There are two levels of side issues in exploring the effectiveness of qualitative research methods. The first level is the human side: beliefs, behaviour, emotions, opinions and individuals' relationships to each other or the surrounding environment. The second level includes the insubstantial factors that can affect the lower level (human side), such as the roles of gender, religion, ethnicity and socioeconomic status.

In the midst of the debate about the superiority of qualitative or qualitative research, Padgett (2004) illustrates that there is a limitation concerning the finding of numeric data (i.e. quantitative) with regard to the social and behavioural sciences. She adds that the dominance of human sounds plays a stronger role than that of numbers and when focus is directed to the narratives and indication of human experience, it helps the research to move from the rigid and deterministic scientific views towards the social reality. In addition, we can extend the findings from qualitative data from a certain population to people of the same characteristics, which helps in establishing precedence eliciting specific social phenomena that can be generalised to other populations or geographic areas (Mack et al., 2005). Rajasekar et al. (2006) clarify that the only way to study patterns is through relationship configuration: "Can we measure or weight patterns? We can not measure or weight patterns. But to study patterns we must map a configuration of relationships" (p. 4).

Creswell (2003) identified five strategies associated with the qualitative approach. The first strategy is ethnographies. where the researcher focuses his/her study on a group of people in their natural setting over a long period of time. Flexibility, reflexivity and reality of observational research data collection are the characteristics of this model (Reeves et al., 2008). The second strategy is Grounded Theory where the researcher uses the actions, views and interactions of the participants of a study to build a general and abstract theory. There are two essential characteristics of this theory design - the regular comparison of different categories of data and the theoretical sampling of data collection - to offer as many similarities and/or differences in the collected information as possible (Charmaz, 2005). The third strategy associated with the quantitative approach is case studies, where the researcher conducts an in-depth investigation of a subject, case, activity or event. The case study sample can include individuals and/or organizations and can be characterised as flexible or rigorous (Baxter \& Jack, 2008).

The fourth strategy is phenomenological research, where the researcher illustrates the essence of the participants' experiences and combines it with his/her own experience to provide an explanation of a human phenomenon. Groenewald (2004) points out that "phenomena have something to say to us" (p. 44). He goes on to say that we are all phenomenologists, poets, painters-even the ordinary person - and each understands and shares life experiences in his/her own way: painters in their drawings, poets in their words and others in their insights into life. The fifth strategy associated with the quantitative approach is narrative research, which is a form of inquiry where the researcher focuses on individuals' lives and their life stories, restores them chronology and 


\section{Mixed Methods Research: An Overview}

collaboratively combines the views of the participants. Moen (2006) indicates that narrative research is a relatively new scope of qualitative research, however, readings about narrative research gives the impression that the focus is spreading in all directions to prove that "case study, a biographical study, a phenomenological study or an ethnographic study may have a narrative form of representation" (p. 57).

Patton (2002) clarifies that deep and rich data are the bases of high quality qualitative studies and that they come from three main kinds of data collection: (1) in-depth, open-ended interviews, (2) notes of direct observations (using narrative descriptions) and (3) written documents. Interviews are open-ended questions and investigations designed to provide the researcher with direct quotations about the respondents' opinions, feelings and in-depth experiences. Observations are detailed and rich fieldwork descriptions of participants' daily personal activities and behaviours and their interpersonal interactions, including their surrounding environments and contexts. Documents can be drawn from written materials completed by participants, such as their responses to open-ended surveys, letters or personal diaries or from other records relating to the participants, such as official documents, organizational forms or other records (Linda et al., $2009 \&$ Trumbull, 2005).

\section{IN-DEPTH FACE-TO-FACE INTERVIEWING}

In-depth interviewing is one of the major sources of data for qualitative research. According to Taylor and Bogdan (1998), indepth interviewing is "repeated face-to-face encounters between the researcher and informants directed toward understanding informants' perspectives in their lives, experiences or situations as expressed in their own words" (p. 77). This definition emphasizes two attributes of in-deep interviewing: the first is that the interview involves repeated face-to-face interaction between the researcher and informant(s). The second is that this repeated contact and the extended length of time of each meeting enhance the sense of confidence between the researcher and the participant(s) and increases the accuracy of the information obtained (Kumar, 2011). Marshall and Rossman (2006) differentiate between a research interview and that of journalists and talk show hosts, in that the former is a purposed conversation in different contexts. In addition, Wengraf (2001) illustrates that distinguishing between the two types can be characterised by speaking about its width rather than its depth. Seidman (2006) adds that the aim of conducting an in-depth interview is not to ask questions and get answers, but to understand others' experiences, their meanings and the details they select.

There are various forms of interviewing, such as telephone interviews, screening interviews, group interviews and behavioural interviews (Gubrium \& Holstein, 2001). However, the most common type of interviewing is individual, face-to-face, verbal interchange (Fontana \& Frey, 2003). Open-ended interviews can be distinguished in reference to three degrees of question structure: structured, semi-structured or unstructured (Grix, 2001). In the structured format, a researcher uses the same set of questions, which are prepared in advance, with all interviewees (Yin, 2011). Unlike structured interviews, a researcher using the unstructured design conducts unguided, open and natural conversations. Cousin (2009) described the line between unstructured and semi-structured interviews as "fuzzy" (p. 71) because "expert interviews always have a structure, which they use flexibly according to what emerges" (Gilham, 2000 cited in Cousin, 2009, p. 71). To provide extra flexibility, a semi-structured design structure based on a set of themes or guidelines facilitates the researcher's conduction of the interview as he/she can modify, restate and add questions to the prepared questions (Cousin, 2009).

O'Hara et al. (2011) clarify that the main advantages and disadvantages of face-to-face interviewing both result from the characteristics of the method. They go further to say that the researcher's direct interaction using un- and semi-structured interviews with the respondent draw directly on his/her views, feelings and thoughts. However, this requires the researcher to be quick-thinking, logical, have a good memory and to be aware of what the other person is saying. These characteristics are important skills for a researcher. Patton (2002) cautions that interviewers should "guard against asking questions that impose interpretations on the situation"(p. 343). In a related view, King (2004) commends the flexibility of qualitative research interviewing that is not formally scheduled on a set of word-for-word questions (ordering of questions), and not limited to certain circumstances, or by time or settings. Nonetheless, interviews, sometimes requiring one to two hours for completion, are time consuming for both the researcher and contributors, which is one of the limitations of this method. Additionally, the researcher must spend many hours transcribing interviews and identifying the parts of the interviews that are relevant to the subject of the research.

King and Horrocks (2010) identify qualitative interviewing as an expensive method. This is due to the obvious need for travelling for the recruitment of interviewees, especially when participants are physically distant. They suggest, based on the nature of the interview topic and participants' availability, that remote interviews replace common face-to-face interviews to limit travel expenses. Interview data collected in a language different from the researchers' native language or one of the primary or common languages usually requires translation (McLellan-Lemal, 2008). Translation through an interpreter adds complexity to data transcripts and requires further time and money expenditure. Possible lack of support and co-operation is another issue that can hinder movement in a qualitative interviewing process (Kvale, 1996). Kvale recommends that researchers obtain a wider network of participants to avoid potential issues with dropping of participants and then data. He further argues that the personal characteristics of respondents, such as non-talking, lack of confidence or inquisitiveness can cause problems in interviews. 


\section{REFERENCE}

1) Ary, D., Jacobs, L., Razavieh A., and Sorensen, C. (2010). Introduction to Research in Education ( $8^{\text {th }}$ ed.). New York: Thomson Wadsworth Group.

2) Baxter P., \& Jack S. (2008). Qualitative Case Study Methodology: Study Design and Implementation for Novice Researchers. The Qualitative Report, 13(4), 544-559.

3) Bryman, A. (2004). Social Research Methods ( $2^{\text {nd }}$ ed.). Oxford: Oxford University Press.

4) Creswell, J. W. (2005). Educational research: Planning, conducting, and evaluating quantitative and qualitative research. Upper Saddle River, NJ: Pearson Education, Inc.

5) Creswell, J. W. (2003). Research design: Qualitative, quantitative and mixed methods approaches (2nd ed.). Thousand Oaks, CA: SAGE Publications.

6) Creswell, J. W. \& Clark, V. L. P. (2007). Designing and conducting mixed methods research. London: Sage Publications.

7) Greene, J. C., Caracelli, V. J., \& Graham, W. D. (1989). Toward a conceptual framework for mixed-method evaluation designs. Educational Evaluation and Policy Analysis, 11(3), 255-274.

8) Charmaz, K (2005). Grounded theory in the 21st Century. in N.K. Denzin \& Y.S. Lincoln (Ed), The sage handbook of qualitative research (pp. 507-535). Thousand Oaks: Sage Publications.

9) Cousin, G. (2009). Researching learning in higher education: an introduction to contemporary methods and approaches. New York: Routledge.

10) Denzin, N.K., \& Lincoln, Y.S. (1994). "Introduction: Entering the field of qualitative research." In N.K. Denzin \& Y.S. Lincoln (Ed.), Handbook of qualitative research. (pp. 1-18). Thousand Oaks: Sage Publications.

11) Denzin, N.K., \& Lincoln, Y.S. (2005). Introduction: The discipline and practice of qualitative research. In N.K. Denzin \& Y.S. Lincoln (Ed), The SAGE handbook of qualitative research (3rd ed) (pp. 1-32). Thousand Oak, CA: The SAGE Publications.

12) Duff, P. (2002). Research approaches in applied linguistics. In R. A. Kaplan (Ed.), The Oxford handbook of applied linguistics (pp. 13-23). Oxford: Oxford University Press.

13) Egan, T.M. (2002). Building theory in HRD from a grounded theory approach. Advances in Developing Human Resources, 4(3), 277-295.

14) Fontana, A., \& Frey, J. H. (2003). The interview: From structured questions to negotiated text. In N. K. Denzin, \& Y. S. Lincoln (Eds.), Handbook of Qualitative research (2nd ed.), (pp. 61-106). United States of America: Sage Publications Ltd.

15) Fred L. Perry Jr. (2011) Research in applied linguistics: Becoming a discerning consumer ( $2^{\text {nd }}$ ed.). New York: Routledge.

16) Gravetter, F., \& Forzano, L. (2003). Research Methods for the Behavioural Sciences. Belmont, CA: Wadsworth.

17) Grix, J. (2001) Demystifying postgraduate research: from MA to PhD. United Kingdom, Birmingham: University of Birmingham Press.

18) Groenewald, T. (2004). A phenomenological research design illustrated. International Journal of Qualitative Methods, 3(1). 42-55

19) Gubrium, J. F., \& Holstein, J. A. (2001). Handbook of Interview Research: Context \& Method. Thousand Oaks, Calif.: Sage Publications.

20) Jenkins, J. E. (2001). Rural adolescent perceptions of alcohol and other drug resistance. Child Study Journal, 31(4), 211-224.

21) Johnson, B., \& Christensen, L. B. (2012). Educational research: Quantitative, qualitative, and mixed approaches (4 ${ }^{\text {th }}$ ed.). United Kingdom, London: SAGE Publications Ltd.

22) Johnson, B., \& Onwuegbuzie A. (2004). Mixed methods research: A research paradigm whose time has come. Educational Researcher, 33(7) 14-26.

23) King, N. (2004). Using interviews in organizational research. In C. Cassell \& G. Symon (Ed.), Essential guide to qualitative methods in organizational research (pp. 11-22). United Kingdom, London: SAGE Publications Ltd.

24) King, N., \& Horrocks, C. (2010). Interviews in Qualitative Research. United Kingdom, London: SAGE Publications Ltd.

25) Kumar, R. (2005). Research Methodology-A Step-by-Step Guide for Beginners (3 $3^{\text {rd }}$ ed.). London: SAGE Publications Ltd.

26) Kvale, S. (1996). Interviews: An Introduction to Qualitative Research Interviewing. Thousand Oaks: Sage.

27) Leedy, P., \& Ormrod, J. (2001). Practical research: Planning and design (7th ed.). Upper Saddle River, NJ: Merrill Prentice Hall. Thousand Oaks: SAGE Publications. 
28) Lodico, M., Spaulding, D., \& Voegtle, K. (2010). Methods in Educational Research: From Theory to Practice. Baltimore: Laureate Education, Inc.

29) Mack, N., Woodsong, C., MacQueen, K., Guest, G., \& Namey, E. (2005). Qualitative research methods: A data collector's field guide. Research Triangle Park, NC: Family Health International.

30) McLellan-Lemal, E. (2008). Transcribing data for team-based research. In Guest G., \& MacQueen K.M. (Ed). Handbook for Team-Based Qualitative Research (pp. 101-118). Lanham, MD: AltaMira Press.

31) Moen, T. (2006). Reflections on the narrative research approach. International Journal of Qualitative Methods, 5(4), 56-69.

32) Molina-Azorin, J and Cameron, R, (2010) The application of mixed methods in organisational research: a literature review. Electronic Journal of Business Research Methods, 8(2), 95-105.

33) Linda G., Morra Imas, and Ray C. Rist (2009). The road to results: Designing and conducting effective development evaluations. Washington, DC: World Bank.

34) O'Hara, M., Carter, C., Dewis, P., Kay, J., \& Wainwright, J. (2011). Successful dissertations: The complete guide for education, childhood and early childhood students. London, UK: Continuum International Publishing Group.

35) Ospina, S. (2004). Qualitative Research. In G. R. Goethals, G. S. Sorenson, \& J. M. Burns (Ed.), Encyclopaedia of leadership (pp. 1279-1284). CA: Thousand Oaks.

36) Padgett, D.K. (2004). Introduction: Finding a middle ground in qualitative research. In D.K. Padgett (Ed), The qualitative research experience (pp. 1-18), Wadsworth, Belmont: Thomson Learning.

37) Patton, M. (2002). Qualitative Research and Evaluation Methods ( $3^{\text {rd }}$ ed.). CA, Thousand Oaks: SAGE.

38) Rajasekar S., Philominathan P. \& Chinnathambi V. (2006). Research methodology, Ar XIV Physics. Retrieved from the Web 14th March 2012, from http://arxiv.org/abs/physics/0601009.

39) Reeves S., Kuper A., \& Hodges B. (2008). Qualitative research methodologies: Ethnography. BMJ; 337.

40) Sale, J., Lohfeld, L., \& Brazil, K. (2002). Revisiting the quantitative-qualitative debate: Implications for mixedmethods research. Quality \& Quantity, 36, 43-53.

41) Seidman, I. (2006). Interviewing as qualitative research: A guide for researchers in education and the social science. Teachers College Press, New York.

42) Shank, G. (2002). Qualitative research: A personal skills approach. New Jersey: Merril Prentice Hall.

43) Tashakkori, A., \& Teddlie, C. (1998). Mixed methodology: combining qualitative and quantitative approaches. Thousand Oaks, CA: Sage.

44) Teddlie, Ch. \& Tashakkori, A (2009). Foundations of mixed methods research: Integrating quantitative and qualitative approaches in the social and behavioural sciences. Thousand Oaks, CA: Sage.

45) Trumbull, M. (2005). Qualitative research methods. In E. G. Taylor (Ed.), Integrating quantitative and qualitative methods in research ( $2^{\text {nd }}$ Ed), (pp. 101-126). Lanham, Maryland: University Press of America.

46) Williams, C. (2007). Research methods. Journal of Business \& Economic Research, 5(3), 65-71.

47) Willis, J.W. (2008). Qualitative research methods in education and educational technology. Charlotte, N.C.: Information Age Publishing, Inc.

48) Yin, R. K. (2011). Qualitative research from start to finish (4 ${ }^{\text {th }}$ ed.). New York: The Guilford Press Publication. 